\title{
Why are Croatian Higher Education Institutions Present on Social Networks?
}

\author{
Kruno Golubić \\ University Computing Centre, University of Zagreb \\ Josipa Marohnića 5, Zagreb, Croatia \\ kruno.golubic@srce.hr \\ Mihaela Banek Zorica \\ Faculty of Humanities and Social Sciences, University of Zagreb \\ I. Lučića 3, Zagreb, Croatia \\ mbanek@ffzg.hr
}

\section{Summary}

Reasons why Croatian higher education institutions are present on social networks and their desired goals have not been researched yet. Previous research studies were mainly focused on the mere presence of institutions and the content they publish, but none of them looked into faculty's opinions (or opinions of persons who are in charge of the official presence of institutions on social networks) about the institutions' presence on social networks and if the outcomes of that presence were as expected. In this paper we will present results of a survey conducted in 2015. The goal of the survey was to find out what do persons that are in charge of the official presence of Croatian higher education institutions on social networks think about it and did it achieve the desired goals. When an institution is deciding whether it should establish presence on any social network or not, experience from other institutions is a valuable input. Therefore, in this paper, we will present some of the key findings on motivation and goal fulfillment of those institutions that have already been engaged on social networks.

Keywords: Croatian higher education, social networks, social network presence, marketing goals, benefits of presence on social networks

\section{Introduction}

With the constant prolongation of time that Internet users spend ${ }^{1}$ on social networks daily, it seems that social networks can no longer be ignored if an institution wants to adequately present itself on the Internet. For quite some time, institutions' web sites have not been the only place for information dissemination.

1 Bennett, Shea. 28\% of Time Spent Online is Social Networking. January $27^{\text {th }} 2015$. http://www.adweek.com/socialtimes/time-spent-online/613474 (5th July 2015) 
A number of research studies conducted during the last few years have shown that Croatian higher education institutions have increasingly started to accept social networks. There has also been a lot of research done about Croatian libraries and their presence on social networks ${ }^{2}$. Studies dealing with Croatian higher education institutions and their presence on social networks were focused either on the mere form of institutions' presence $^{3}$ on social networks, or the use of social networks in communication ${ }^{4}$. The research was mainly based on publicly available data published by institutions.

These research studies gathered valuable data about the institutions' presence, published content and communication, but none of the published papers focused on the reasons why institutions use social networks and whether they achieved their goals. When an institution is deciding about establishing its presence on social networks, experience from other institutions is a valuable input. In this paper we will present some of the key findings on motivation and goal fulfillment of those institutions that have already been engaged on social networks.

\section{Research}

This paper is a part of an ongoing research project started a few years ago with a goal to map the usage of social networks among Croatian higher education institutions $^{5}$. The goal of this paper is to find out the reasons why higher education institutions are present on social networks and to provide an insight into institutions' views and opinions about social networks as well as the benefits that their usage brings them. Along with the institutions' motivation and goals, we also wanted to see if institutions are using any kind of marketing activities on social networks and are those activities achieving the desired results.

\footnotetext{
${ }^{2}$ Umreženi : društvene mreže i knjižnice u Hrvatskoj : zbornik radova / Šalamon-Cindori, B. (ed.). Zagreb : Nacionalna i sveučilišna knjižnica u Zagrebu, 2015. http://nsk.hr/umrezenidownload.php

${ }^{3}$ Golubić, Kruno; Lasić-Lazić, Jadranka. Analysis of On-line Survey about Need for Presence of Higher Education Institutions on Social Networks: a Step Towards Creation of Communication Strategy. // CIT: Journal of computing and information technology. 20 (2012) , 3; pp.189-194

${ }^{4}$ Delić, Alen; Grd, Petra; Gregurec, Iva. Analysis of Communication of Croatian Faculties through Facebook - Part I. // In Proceedings of the ITI 2013 35th International Conference on Information Technology Interfaces / Luzar-Stiffler, Vesna ; Jarec, Iva (ed.). Zagreb: Srce - University Computing Centre, University of Zagreb, 2013, pp. 43-48.

${ }^{5}$ Golubić, Kruno. The official presence of Croatian higher education institutions on social networks. // In Proceedings of the 3rd International Conference The Future of Information Sciences (INFuture) / Billeness, C ; Hemera, A. ; Mateljan V. ; Banek Zorica, M ; Stančić, H. ; Seljan, S. (ed.). Zagreb: Department of Information Sciences, Faculty of Humanities and Social Sciences, University of Zagreb, 2011, pp. 263-275.
} 
Since this is a research about online activities, use of an online survey tool seemed like a logical choice. The survey was created using SurveyGizmo ${ }^{6}$ online survey tool. The survey consisted out of 23 questions in total. They were spread across 9 pages.

The survey had five main sections:

- General data

- Presence on social networks

- Marketing activities and fulfilment of goals

- Communication over social networks

- Opinions and views about social networks

All of the questions were marked as required. Single and multiple choice questions were used across the survey. Open text fields were used only when additional information was needed from the participants. In the middle of the survey, branching was used to display additional questions to those institutions that use social networking for marketing activities. At the very end, there were three questions that consisted out of 25 statements and opinions. Participants had to select the degree of agreement or disagreement with those statements. For those last three questions, Likert scale ${ }^{7}$ was used. The Likert scale allowed us to get a better insight into institutions' opinions and views on specific topics. Due to a large amount of gathered data, especially from the last three questions, not all results will be presented in this paper.

After the internal testing of the survey's form and logic, the next step was sending out invitations. The survey was sent out to those institutions already present on social networks and previously identified by another research ${ }^{8}$. The invitation with a link to the online survey was either sent via direct messaging feature on Facebook, or via e-mail. In total, 53 institutions received the invitation. The survey was active for one month, from $22^{\text {nd }}$ April until $22^{\text {nd }}$ May 2015.

\section{Findings}

\section{General data}

Out of the 53 invited institutions, 30 of them are publicly funded (54\%) and 23 are privately funded (46\%) institutions. During the aforementioned one month period, the survey was opened 33 times. Out of those 33 times, in 9 cases the

\footnotetext{
${ }^{6}$ More information about SurveyGizmo can be found at their web site at http://www.survey gizmo.com/.

${ }^{7}$ Brace, Ian. Questionnaire Design: How to Plan, Structure and Write Survey Material for Effective Market Research. London, Philadelphia, Kogan Page, 2008, p. 73.

${ }^{8}$ Golubić, Kruno; Banek Zorica, Mihaela. Presence and Activity of Croatian Higher Education Institutions on Social Networking Sites. // Proceedings of the 25th Central European Conference on Information and Intelligent Systems / Hunjak, T.; Lovrenčić, S.; Tomičić, I. (ed.). Varaždin: Faculty of Organization and Informatics, University of Zagreb, 2014, pp. 102-107.
} 
surveys were partially filled out and in 24 cases, the surveys were completed, which means that the survey's response rate was $45 \%$. No subsequent reminder was sent to those participants who started filling out the survey, but did not finish it. All incomplete surveys were discarded $(\mathrm{N}=9)$. None of the completed surveys were duplicates.

We consider this to be a good response rate when compared ${ }^{9}$ with some stand$\operatorname{ards}^{10}$. Only the data from 24 completed surveys was used for this research. Both publicly and privately funded institutions were represented with 12 responses each.

At the very beginning of the survey, participants were asked if they were in any way responsible for the institution's presence on social networks. Only those participants that answered "Yes" were allowed to fill out the survey, while the rest were disqualified. There were no disqualified participants, probably due to the direct targeting of the participants.

\section{Content selection}

Most of the surveys ( $\mathrm{N}=22)$ were filed out by one of the institution's employees. None of the respondents were students. One respondent stated that he/she is an employee of an external agency in charge for the presence of the institution on social networks. The remaining respond was marked as "Other".

Creating content and curation for social networks, as well as communicating via social networks, can be a rather demanding tasks. We wanted to find out how many people are involved in those tasks (Table 1). As it can be seen from the results, one third of the institutions has only one person in charge of the content and the large majority of institutions think that this is not a task for only one person. This shows that institutions care about their presence on social networks and they want to be adequately presented.

Almost half of the institutions (Table 2) do not have clear rules on the selection process of content that is being published. This means that people in charge of publishing hold great responsibility regarding the selection of content. As it can be seen from the data, employees and students are contributing to the process of content gathering. We believe that this is an example of good practice. Higher education institutions have very diverse fields of interest within themselves. Inputs from multiple sides allow institutions to cover more fields of interest and consequentially, this brings them better reputation in the community.

\footnotetext{
${ }^{9}$ Stoop, Ineke A.L. The Hunt for the Last Respondent. Hague: Social and Cultural Planning Office, 2005, page 23

${ }^{10}$ Ficker Jr., Ronald Sampling methods for web and e-mail surveys. // The SAGE Handbook of Online Research Methods / Fielding N., Lee R., Blank G. (Ed.). London: SAGE Publications Ltd, 2008, pp. 195-216.
} 
Table 1. Number of people in charge for the presence on social networks

\begin{tabular}{|l|c|}
\hline Number of people in charge & Number of institutions \\
\hline 1 & 8 \\
\hline 2 & 6 \\
\hline 3 to 5 & 10 \\
\hline 6 or more & 0 \\
\hline
\end{tabular}

Table 2. Rules and content guidelines

\begin{tabular}{|l|c|}
\hline \multicolumn{1}{|c|}{ Existence of rules } & Number of institutions \\
\hline $\begin{array}{l}\text { There are clear rules that define types of content to be published on } \\
\text { social networks }\end{array}$ & 13 \\
\hline $\begin{array}{l}\text { Content is generated based on information published on } \\
\text { institution's web page }\end{array}$ & 21 \\
\hline Employees provide content for publishing & 18 \\
\hline Students provide content for publishing & 14 \\
\hline I don't know & 0 \\
\hline
\end{tabular}

\section{Presence on social networks}

According to the survey, all institutions have been present on social networks for at least two years. The longest running ones have been present for seven years (Table 3). If we look at the number of institutions that started using social networks in a particular year, we can see that 2012 was the year when the largest number of individual institution established its presence on social networks. We believe that these higher education institutions are conservative in their essence, and therefore they do not belong to early adopters of technologies and trends. They rather wait for maturity of trends and concepts before adopting them into their everyday routine.

Table 3. Presence of institution on social networks

\begin{tabular}{|l|c|}
\hline \multicolumn{1}{|c|}{ Year } & Number of institutions \\
\hline 2013 & 3 \\
\hline 2012 & 7 \\
\hline 2011 & 3 \\
\hline 2010 & 3 \\
\hline 2009 & 3 \\
\hline 2008 & 1 \\
\hline I don't know & 4 \\
\hline
\end{tabular}

The presence on specific social networks is not the focus of this paper, but we believe that it is important to make a note which social networks were identified as the most popular ones among institutions. Participants were given a multiple choice question, a list of social networks identified by a previous research ${ }^{11}$.

${ }^{11}$ Golubić, Kruno; Banek Zorica, Mihaela. Presence and Activity of Croatian Higher Education Institutions on Social Networking Sites. // Proceedings of the 25th Central European Conference on Information and Intelligent Systems / Hunjak, T.; Lovrenčić, S.; Tomičić, I. (ed.). Varaždin: Faculty of Organization and Informatics, University of Zagreb, 2014, pp. 102-107. 
The fact that not one institution selected the option "Some other social network" shows that the list of social networks was appropriate for this research. The popularity of social networks is as expected. (Table 4).

Table 4. Presence on social networks

\begin{tabular}{|l|c|}
\hline \multicolumn{1}{|c|}{ Social network } & Number of institutions \\
\hline Facebook & 24 \\
\hline Twitter & 16 \\
\hline YouTube & 19 \\
\hline LinkedIn & 12 \\
\hline Google+ + & 7 \\
\hline Tumblr & 0 \\
\hline Instagram & 4 \\
\hline Flickr & 1 \\
\hline Vimeo & 6 \\
\hline I'm not sure & 0 \\
\hline Some other social networks & 0 \\
\hline
\end{tabular}

\section{Marketing activities and fulfilment of goals}

According to the survey, 13 institutions have advertised on social networks. Privately funded institutions $(\mathrm{N}=9)$ are majority of institutions that have advertised on social networks. In the multiple choice question about advertising goals (Table 5), all institutions responded that attraction of students was one of their goals. From the other selected goals, it can be seen that institutions are eager about informing the general public about their work and accomplishments.

Table 5. Advertising goals

\begin{tabular}{|l|c|}
\hline \multicolumn{1}{|c|}{ Advertising goal } & Number of institutions \\
\hline Attracting students to institution & 13 \\
\hline Find associates for projects & 3 \\
\hline Present work results of institution & 9 \\
\hline Increase recognisability of institution & 11 \\
\hline Increase visibility in local community & 7 \\
\hline Other goals & 2 \\
\hline I don't know & 0 \\
\hline
\end{tabular}

According to the answers, institutions are satisfied with their advertising activities (Table 6). Not one institution answered that no goals were achieved, and the majority of institutions were satisfied with the achievement of advertising goals. This shows us that advertising over social networks brings benefits to institutions.

Table 6. Fulfilment of advertising goals

\begin{tabular}{|l|c|}
\hline \multicolumn{1}{|c|}{ Fulfilment of advertising goals } & Number of institutions \\
\hline All goals were accomplished & 3 \\
\hline Larger portion of goals was accomplished & 9 \\
\hline Smaller portion of goals was accomplished & 1 \\
\hline
\end{tabular}




\section{Communication over social networks}

Quick and easy communication is one of the key components and features of social networks. At this point, we were not interested in the communication with the general public, but rather in the communication with two groups of people that are tightly connected with institutions (Table 7). Those two groups are students and employees (including associates). A large majority of institutions $(\mathrm{N}=9)$ have stated that they do not use social networks for direct (i.e. private) communication with those two groups. Since this was a multiple choice question, we can see that some institutions use social networks to communicate directly with both groups.

Table 7. Use of social networks for communication

\begin{tabular}{|l|c|}
\hline \multicolumn{1}{|c|}{ Private communication with certain group } & Number of institutions \\
\hline Communication with students & 2 \\
\hline Communication with employees and associates & 1 \\
\hline Communication with students, employees and associates & 1 \\
\hline There is no private communication over social networks & 9 \\
\hline
\end{tabular}

All institutions $(\mathrm{N}=3)$ that communicate with students provide only general information, e.g. working hours of the registrar or the accounting service. None of them stated that they provide more specific information, such as exam schedule and results. In communication with employees, all institutions $(\mathrm{N}=2)$ provide only general information as well. In addition to those information, one of the institutions stated that they provide individual exam results to staff members via social networks.

According to the results, formal communication via social networks is the weakest link in the institutions' presence on social networks. We believe that the lack of formal communication lies in the fact that it is hard to prove someone's identity while communicating via social networks. This limits the communication mainly on providing general information, and in the rare cases when there is trust in someone's identity, more sensitive information and data is communicated.

\section{Opinions and views on social networks}

We believe that the support given by the institutions' management shows that the benefit of presence on social networks has been recognized and is considered to be a valuable asset. To find out more about the benefits of that presence for institutions, participants were asked to rate their views on several possible benefits. To rate their opinions and views, we have used the five point Likert scale (Table 8). Ratings on the scale were as following:

- Strongly agree (1)

- Agree (2)

- Neither agree nor disagree (3) 
- Disagree (4)

- Strongly disagree (5)

Table 8. Opinions and views on social networks

\begin{tabular}{|c|c|c|c|c|c|}
\hline \multirow{2}{*}{ Statement } & \multicolumn{5}{|c|}{ Rating on Likert scale and number of responses } \\
\hline & 1 & 2 & 3 & 4 & 5 \\
\hline $\begin{array}{l}\text { My institution has benefits from } \\
\text { presence on social networks }\end{array}$ & 16 & 6 & 2 & 0 & 0 \\
\hline $\begin{array}{l}\text { My institution has official } \\
\text { communication strategy }\end{array}$ & 4 & 9 & 6 & 4 & 1 \\
\hline $\begin{array}{l}\text { Management of my institution supports } \\
\text { presence on social networks }\end{array}$ & 13 & 8 & 3 & 0 & 0 \\
\hline $\begin{array}{l}\text { Due to presence on social networks my } \\
\text { institutions is more successful at } \\
\text { attracting new students }\end{array}$ & 5 & 14 & 5 & 0 & 0 \\
\hline $\begin{array}{l}\text { Due to presence on social networks my } \\
\text { institution is more successful at finding } \\
\text { new associates for projects }\end{array}$ & 2 & 5 & 14 & 3 & 0 \\
\hline $\begin{array}{l}\text { Due to social networks it is easier for my } \\
\text { institution to present result of its work }\end{array}$ & 8 & 11 & 5 & 0 & 0 \\
\hline $\begin{array}{l}\text { Due to presence on social networks my } \\
\text { institution is more recognisable and } \\
\text { visible in local community }\end{array}$ & 6 & 12 & 5 & 1 & 0 \\
\hline
\end{tabular}

Due to the fact that the survey was conducted among institutions that use social networks, it is no surprises that most opinions about social networks are positive ones. Only the statement about finding new associates for projects can be considered as neutral one.

It can be seen that institutions have benefited from presence on social networks in many different ways:

- Students are more easily attracted to the institution

- Institution is more visible in the community

- Presentation of work results is easier

Based on the answers, we can see that even if the institutions do not use social networks for advertising, they can gain the same benefits as those that do. All those benefits can be considered as building blocks, used to build up the institutions' on-line reputation. We believe that all benefits are tightly interlaced, e.g. institutions that present their results on-line are more visible and therefore they attract students more easily.

\section{Conclusion}

Institutions' managements are supporting presence on social networks and considerable human resources are dedicated to this task. Content published on social networks is gathered from different sources. Important role in content gathering belongs to the staff members and students that provide content for publishing. It is surprising that some institutions do not have an official communi- 
cation strategy. Such strategy can be very useful to prevent unwanted situations, e.g. in situations when several persons are in charge of communication, a clear set of rules would make task handling much easier. We believe that a communication strategy would make a job of content handling much easier for persons in charge of it.

Almost all institutions are taking care of their own presence on social networks and only in rare cases this job is done by specialised agencies. Since institutions have been present on social networks for more than couple of years, and none of them have joined social networks in the last year, we consider social networks mature enough to be considered as an official communication channel. Institutions that are not already present on social networks should take steps towards social networks in the near future, if they also want to benefit from them, for example, attract new students, achieve better visibility of the institution and profit from it.

Presence on social networks does not mean that marketing activities are the imperative, but they are a welcoming addition for achieving the desired goals. Due to a large number of users, social networks make an excellent platform for marketing activities. Many institutions have already recognised this and they are satisfied with the results of their ongoing marketing activities.

There are many benefits for institutions that use social networks. Those benefits are not limited only to institutions that use social networks for marketing activities. Social networks make the presentation of results easier for institutions. They are also more visible in community and better at attracting new students.

Lack of direct communication over social networks can be explained by the fact that, due to the nature of social networks, it is not always possible to prove someone's identity. This limits communication mostly to the exchange of general information, while private date is omitted and not being transferred. We believe this will not change in the near future.

Social networks cannot be considered as a passing trend. As time passes by, they are becoming more and more important as a medium for information dissemination. This means that institutions need to keep up with the latest trends in this ever-changing landscape of Internet. Not all trends should be accepted, but after careful consideration, focus should be put on the most important ones.

\section{References}

Bennett, Shea. $28 \%$ of Time Spent Online is Social Networking. January $27^{\text {th }} 2015$. http://www.adweek.com/socialtimes/time-spent-online/613474 (5th July 2015)

Brace, Ian. Questionnaire Design: How to Plan, Structure and Write Survey Material for Effective Market Research. London, Philadelphia: Kogan Page, 2008.

Delić, Alen; Grd, Petra; Gregurec, Iva. Analysis of Communication of Croatian Faculties through Facebook - Part I. // In Proceedings of the ITI 2013 35th International Conference on Information Technology Interfaces / Luzar-Stiffler, Vesna ; Jarec, Iva (ed.). Zagreb: Srce - University Computing Centre, University of Zagreb, 2013, pp. 43-48. 
Ficker Jr., Ronald Sampling methods for web and e-mail surveys. // The SAGE Handbook of Online Research Methods / Fielding N., Lee R., Blank G. (Ed.). London: SAGE Publications Ltd, 2008, pp. 195-216.

Golubić, Kruno. The official presence of Croatian higher education institutions on social networks. // In Proceedings of the 3rd International Conference The Future of Information Sciences (INFuture) / Billeness, C ; Hemera, A. ; Mateljan V. ; Banek Zorica, M ; Stančić, H. ; Seljan, S. (ed.). Zagreb: Department of Information Sciences, Faculty of Humanities and Social Sciences, University of Zagreb, 2011, pp. 263-275.

Golubić, Kruno; Banek Zorica, Mihaela. Presence and Activity of Croatian Higher Education Institutions on Social Networking Sites. // Proceedings of the 25th Central European Conference on Information and Intelligent Systems / Hunjak, T.; Lovrenčić, S.; Tomičić, I. (ed.). Varaždin: Faculty of Organization and Informatics, University of Zagreb, 2014, pp. 102-107.

Golubić, Kruno; Lasić-Lazić, Jadranka. Analysis of On-line Survey about Need for Presence of Higher Education Institutions on Social Networks: a Step Towards Creation of Communication Strategy. // CIT: Journal of computing and information technology. 20 (2012), 3; pp.189194

Stoop, Ineke A.L. The Hunt for the Last Respondent. Hague: Social and Cultural Planning Office, 2005.

Umreženi : društvene mreže i knjižnice u Hrvatskoj : zbornik radova / Šalamon-Cindori, B. (ed.). Zagreb : Nacionalna i sveučilišna knjižnica u Zagrebu, 2015. http://nsk.hr/umrezenidownload.php (8th October 2015) 